\title{
Solidarity Through Localization? Humanitarian Responses to the COVID-19 Pandemic
}

\author{
Charlotte Dany * \\ Managing Director of the Peace Academy Rhineland-Palatinate at the University of Koblenz-Landau, Landau, Germany
}

This contribution discusses whether humanitarian aid is a suitable tool for expressing global solidarity in the COVID-19 pandemic. Based on the distinction between the concepts of humanitarianism and solidarity, as well as the example of the so-called "refugee crisis," it provides a mixed answer: humanitarian aid and solidarity are, principally, different things, hardly comparable and, at times, even contradictory. However, the corona pandemic presents an opportunity for localization of humanitarian aid, which is an opportunity for greater solidarity with those most in need. To make humanitarian aid a real tool for expressing global solidarity, one would have to regard the recipients of aid as equals and strengthen their agency, as well as that of local and grassroots organizations in the most affected areas - much as the localization agenda demands.

\section{OPEN ACCESS}

Edited by: Kilian Spandler, University of Gothenburg, Sweden

Reviewed by:

Stefano Palestini,

Pontificia Universidad Católica de

Chile, Chile

Sulagna Maitra,

University College Dublin, Ireland

*Correspondence:

Charlotte Dany

dany@uni-landau.de

Specialty section: This article was submitted to Peace and Democracy, a section of the journal Frontiers in Political Science

Received: 15 April 2021 Accepted: 30 September 2021 Published: 15 October 2021

Citation:

Dany C (2021) Solidarity Through Localization? Humanitarian Responses to the COVID-19 Pandemic. Front. Polit. Sci. 3:695654. doi: 10.3389/fpos.2021.695654
Keywords: humanitarian aid, COVID-19, solidarity, refugees, localization

\section{INTRODUCTION}

Europe and the United States have been struggling with particularly high COVID-19 infections and deaths during the past one and a half years. In contrast, poor and conflict-ridden countries in Africa and Western Asia seem relatively less affected by the pandemic-at least at first sight. Somalia, Congo, Sudan, South-Sudan, Chad, and the Central African Republic, as well as Yemen and Syria reported only very moderate numbers of infections. ${ }^{1}$ Yet, this does not necessarily mean that they are less affected. While at first, it seemed that a lack of data was deceptive about actual infection rates, seemingly explaining the low number of $\operatorname{cases}^{2}$, as of the time of writing, infection rates are rising rapidly in some African countries, such as in the DR Congo and Namibia. There is thus great fear of COVID-19 hitting countries with especially weak health care systems, high conflict, and lack of vaccines. $^{3}$

Irrespective of the actual infection rates, the pandemic is felt most existentially by people and societies in greatest need of development aid and humanitarian assistance. In particular people living in conflict zones or refugee camps are not able to protect themselves adequately from the spread of the virus, as a British doctor and humanitarian worker explains: they "cannot physically distance, they cannot self-isolate, they have inadequate facilities for washing, and are often without access to

\footnotetext{
${ }^{1}$ Data on infection rates is taken from Johns Hopkins University \& Medicine, Coronavirus Resource Center, at https:// coronavirus.jhu.edu/map.html. A World Health Organization map focuses on cases in Africa specifically at https://who.maps. arcgis.com/apps/dashboards/0c9b3a8b68d0437a8cf28581e9c063a9.

${ }^{2}$ Katherine Houreld, David Lewis, In Africa, lack of coronavirus data raises fears of 'silent pandemic', Reuters, 8 July 2020, https://www.reuters.com/article/us-health-coronavirus-africa-data-insigh-idUSKBN24910L (checked on 29 September 2021) ${ }^{3}$ Coronavirus in Africa: Concern growing over third wave of Covid-19 infections, BBC News, 7 June 2021, https://www.bbc. com/news/world-africa-53181555 (checked on 29 September 2021).
} 
health care" (Nott, 2020, p. 1533). Besides these rather obvious direct detriments, vulnerable people also suffer most from longerterm socio-economic effects of the pandemic. Refugees and migrants, for example, are not only exposed to additional health risks in overcrowded refugee camps, but are further limited by additional restrictions in the COVID-19 pandemic: While refugees already have a limited ability to advance their economic situation, the pandemic took further opportunities of work or education from them (Etzold, 2020, p. 13). A current report further highlighted that COVID-19 has fatally reduced measures to prevent and control other deadly diseases, such as HIV/AIDS, tuberculosis, or malaria (The Global Fund, 2021). Thus, poor and conflict-ridden states of the Global South are prone to suffer most strongly from the pandemic in the short- and long-terms.

On this background it is not astonishing that, according to UN estimates, the COVID-19 pandemic has accounted for a $40 \%$ increase in humanitarian needs in 2020 (OCHA, 2020). As a consequence, existing inequalities are exacerbated. The pandemic increases the divide between rich and poor countries, between donors and recipients of aid, between privileged mobile elites and precarious low-income labor migrants and refugees, a divide that is further constraining their life prospects. In this situation, calls for solidarity are getting louder-which means, generally, a feeling of connectedness with and calls for more equality and justice for people that are most affected by the pandemic. Solidarity is particularly hard to achieve for those who are living outside of one's own community, or even in far-away countries.

This contribution discusses what humanitarian aid can do in this situation. In particular, can it be a tool for expressing such global solidarity in the COVID-19 pandemic? This contribution first explains that solidarity and humanitarianism are separate concepts and don't go well together. In particular, solidarity focuses on political equality and rights, whereby humanitarian aid (often, albeit not always) tries to keep a distance from these political concepts. To be sure, humanitarianism has been thoroughly entangled with human rights, throughout its history and also in current practice (see, Barnett, 2020). But humanitarianism is particularly wary with regard to the rights- and justice-demands of the human rights agenda, which also come along with calls for solidarity (Barnett, 2020, p. 3). Humanitarian actors are concerned that including the language and practices of human rights work might blur boundaries to political motivations and actions, hindering them to do their important work: saving lives and helping people in great need. Humanitarian aid should thus not be overburdened with far-reaching demands they cannot meet. However, this contribution further argues that the pandemic reinforced the localization agenda in humanitarian aid, and by way of this presents a chance for more solidarity within humanitarian practice. In some conflict-ridden and poor countries local initiatives emerged for protection and prevention in this global health crisis. The localization agenda in humanitarian aid seeks to strengthen these local actors and initiatives to overcome established donor-receiver relations. By way of localization, humanitarian aid may help to achieve common goals among equals and thus to integrate a more solidarity-focused approach that empowers the receivers of aid.

\section{CALLS FOR SOLIDARITY AND HUMANITARIAN AID IN THE COVID-19 PANDEMIC}

From early on comments had presented the COVID-19 pandemic as a chance to enhance international cooperation and global solidarity. In March, a development expert interpreted the exchange of medical equipment and expertise between countries as the beginning of a "new approach to international cooperation" (Prizzon, 2020) that would break down the traditional roles of donors and recipients. Even after initial optimism has faded and 2020 has drawn to a close with particularly high infection rates in many countries across the world, UN Secretary-General António Guterres depicted COVID-19 as a chance for fundamental change if it would only lead to more global solidarity and international cooperation (UN News, 2020). Solidarity has become the authoritative national and global guiding concept for seizing the opportunities offered by the pandemic (Lucke, 2021, p. 7, p. 7).

Despite the vast calls for solidarity, global solidarity is however rather missing in the COVID-19 pandemic. First of all, "financial pledges and actual commitments to lowerincome countries are woefully inadequate" (Razavi et al., 2020 , p. 72). Moreover, the global distribution of vaccines shows a lack of solidarity, as scarce vaccines are not being made available for the most vulnerable people in other countries, but rather used by governments for their own populations first. Although the COVAX initiative tries to counter this rampant vaccine nationalism and by way of this might further global solidarity, it does not yet achieve its goal and lacks sufficient doses (Bogdandy and Villareal, 2020).

Not least, the situation of refugees has further worsened since March 2020. COVID-19 was certainly not the cause of closed borders, violence, human rights violations, overcrowded refugee camps and insecure routes to (often) European countries. Nevertheless, it served to further inflame conflicts over the admission of refugees and over their often inhumane situation-literally, when flames engulfed the Moria refugee camp after a COVID-19 outbreak (Etzold, 2020 , p. 10). This situation reinforced calls for solidarity with refugees, but also with those border countries of the European Union (EU) coping with particularly high numbers of arriving refugees. Among others, the EU itself made proposals for a solidarity-based approach to refugees in response to the pandemic. In September 2020, the EU Commission called on member states to show solidarity by dealing with refugees in a long-term and solidarity-based manner. Member states were to implement programs for safe escape routes to Europe and resettlement in safe 
environments (European Commission, 2020, p. 1) However, in the same document, the Commission bemoaned that the current pandemic has put new constraints on emerging EU programs that were established to achieve such goals (European Commission, 2020, p. 4). The virus has been further used as an excuse to prevent refugees from entering the EU, either by further limiting the admission of refugees to the EU or by impeding search and rescue operations on the Mediterranean Sea (Ärzte ohne Grenzen, 2020; Etzold, 2020, p. 17). Solidarity with refugees as well as with vulnerable people in poor and conflict-ridden states is still patently absent, particularly during this pandemic.

What could humanitarian aid organizations do in this situation? The idea that global solidarity could be achieved through the delivery of humanitarian aid has gained new ground during the pandemic. For example, the German foreign minister and the European Commission's Department for Humanitarian Aid are of the opinion that humanitarian aid would be one way to express solidarity with those most in need (Auswärtiges Amt, 2018; 2020a; 2020b; ECHO, 2008). The United Nation's calls for global solidarity in the COVID-19 pandemic also strongly count on the humanitarian system, especially in vulnerable and conflict-ridden countries with weak health systems (UN News, 2020, p. 6). As a matter of fact, since March 2020, big humanitarian donors have stepped up their spending on aid. Germany increased its humanitarian aid budget to $€ 2.1$ billion in 2020. Humanitarian organizations have also tried to maintain their projects as best as possible, although they face particularly high challenges-for instance, travel restrictions have reduced access to certain countries (Bandsom, 2020). Despite these high hopes and efforts in the field of humanitarian aid, it is however questionable whether solidarity can be achieved by humanitarian aid. Although the much too often careless use of solidarity in political statements suggests otherwise, the scientific literature proposes that solidarity and humanitarianism are highly specific concepts and don't go too well together.

\section{HUMANITARIANISM AND SOLIDARITY: DIFFERENCES AND OVERLAPS}

While they share some common ground, "humanitarianism" and "solidarity" should be differentiated and not used synonymously. The main aim of humanitarian aid is to save and protect human lives (Slim, 2015, p. 2)-which is a very difficult, but at the same time also moderate aim. For this purpose, humanitarian aid organizations provide relief goods and medical care, ideally in the short-term, in the context of disasters and conflict. The ethical basis for humanitarian aid is found in humanitarianism. Humanitarianism is the idea to provide compassion and relief to people in immediate need through impartial, neutral, and independent humanitarian aid-which deliberately demarcates it from political activities (Barnett 2005, p. 724). While solidarity also includes compassion for others in need and the will to reduce suffering, it is more ambitious in its aims and more political than humanitarian aid.
"Solidarity" has many meanings in everyday language, and as a theoretical and philosophical concept. Its core meaning is as a morally binding obligation within communities. It arises through the identification of relevant commonalities (Derpmann, 2020, p. 2). This is supposed to create a sense of equality. Solidarity targets inequalities and seeks to enhance the common good by standing side-by-side with others in a reciprocally supportive relationship. Therefore, solidarity is not only a moral obligation but also a political demand (Derpmann, 2020, p. 3). It is achieved through a sense of equality: solidarity targets inequalities and seeks to enhance the common good by standing side-by-side with others as equals in a reciprocally supportive relationship. The context of humanitarian aid demands the expression of solidarity across borders; this is particularly hard to achieve because communities and commonalities are harder to define internationally. Solidarity might draw on the common idea that all humans deserve a life of dignity and integrity, giving it some common ground with humanitarianism. However, apart from humanitarian aid, solidarity also entails reciprocity, a sense of community, and working towards a common goal (Wagner, 2019, p. 89). It requires action that protects against the factors that cause harm and suffering, including, for example, street protests. Solidarity further demands governments and agencies to work together with refugees and migrants as equal partners. Because of this genuinely political nature of solidarity and its demand for equality, it is in tension with humanitarian aid.

In a recent anthology on Humanitarianism and Human Rights, edited by Michael Barnett, authors draw on Hannah Arendt to argue feelings such as compassion and pity as unsuitable for establishing equality between individuals (Flynn, 2020, p. 55). Instead, humanitarian aid has been criticized for establishing unequal and patriarchal relationships (Ticktin, 2014, pp. 278-279). Following this line of reasoning, existing inequalities are reinforced through the narratives of "victims" who need to be redeemed by "rescuers," and through suppressing the voices and identities of those in need (Barnett, 2020, p. 15). This acts to stabilize and perpetuate existing inequalities and runs counter to the idea of solidarity, which is expressed through reciprocal connectedness between equals. A merely humanitarian response can, therefore, be counterproductive to achieving solidarity. At the same time, demands to eliminate the root causes of suffering and the inherently political nature of solidarity contravenes the moderate aims and largely unpolitical nature of humanitarian aid.

However, these distinctions and even contradictions should not veil that humanitarianism and more political kinds of activities, such as human rights work, may be combined in practice. Flynn takes as example the letter-writing campaigns of Amnesty International in the 1960's. By writing letters to prisoners of consciousness this human rights organization would show solidarity by focusing on suffering individuals (Flynn, 2020, p. 68). Moreover, over the past two decades, humanitarian organizations have increasingly recognized their "points of intersection with politics," thereby also trying to "transform the world" (Barnett, 2005, p. 734). This opens the door for a new kind of humanitarian activism that is oriented towards achieving solidarity. 
Such a form of solidarity-humanitarianism emerged, for example, during the heyday of the so-called refugee crisis. As unprecedented numbers of people in need reached Europe, new actors (volunteers and search-and-rescue organizations) joined with traditional humanitarian organizations in organizing help in refugee camps, along the refugee routes and on the Mediterranean Sea. Some have argued that this established-at least in a certain time and place-a more egalitarian, antihierarchic and less institutionalized humanitarian response at the European border: "solidarity humanitarianism" (Rozakou, 2017, p. 99). This solidarity humanitarianism was driven by new actors. Ordinary local residents formed spontaneous initiatives-or Citizen initiatives for global solidarity (CIGS)-on the Greek island Lesvos, to help refugees that arrived in great numbers at the shore (Haaland and Wallevik, 2020). The citizen initiatives were critical of the traditional aid industry, and can even be interpreted as acts of resistance (Haaland and Wallevik, 2020, p. 1872). They resisted, for example, by refusing to talk about "refugees" in general, rather taking those arriving "as people with histories, experiences, identities and, not least, opportunities" (Haaland and Wallevik, 2020, p. 1878). In this regard, these spontaneous citizen initiatives expressed solidarity with people on the move and tried to abstain from introducing a hierarchy between "rescuers" and "victims." Such moves are also demanded by those that criticize traditional humanitarian aid for leaving the rights of refugees aside and abstaining from broader political engagement during the recent "refugee crisis," rather focusing on life-saving medical and other support (van Dyk, 2020, pp. 44-45). Although the "refugee crisis" triggered some more politicized activities by traditional humanitarian aid organizations, such as Doctors without Borders (MSF) (Dany, 2019), these organizations are still restricted in showing solidarity. They are bound by their restrictive mandate to save lives and prevent suffering and by the need to avoid overt political positioning.

So far, this contribution has discussed whether humanitarian aid is a suitable tool for expressing global solidarity, using the example of current developments in the context of migration and refugees in the EU. The answer is mixed: humanitarian aid and solidarity are, principally, different things, hardly comparable and, at times, even contradictory. Some developments in the response to the "refugee crisis" can be interpreted as one step towards a more solidarity-oriented humanitarianism; however, global solidarity requires to regard refugees as equals and strengthen their agency, as well as that of local and grassroots organizations in the most affected countries (home, transit and receiving countries)-much as the localization agenda demands. The remaining article will present some experiences from the COVID-19 pandemic, to explore developments in the aid sector during the pandemic. Lessons learnt from particularly conflict-ridden countries suggest that the pandemic facilitated a localized approach to humanitarian aid, which is promising not least with regard to the much-needed solidarity in the pandemic. Localization could contribute to more solidarity in humanitarianism, if it strengthens the agency of local actors.

\section{DISCUSSION: COVID-19-A BOOST FOR THE LOCALIZATION AGENDA AND A CHANCE FOR SOLIDARITY?}

The localization agenda has shaped discussions since the 2016 UN World Humanitarian Summit in Istanbul. Although it is inadequately conceptualized what localization and "the local" means (Roepstorff, 2020), it inspired a broad debate about how the local could be integrated in policy-making and implementation: while some critical assessments question the desirability of localization (Schenkenberg, 2016), the localization agenda has mainly raised hopes for a less hierarchic and patriarchic relationship between donors and receivers of aid. Localization requires humanitarian assistance to be increasingly delivered by organizations or affected people in disaster-prone regions of the Global South themselves, as it is assumed that their actions are more accepted and they can better anticipate the effects of their actions through local expertise. International humanitarian NGOs, on the other hand, which often have their headquarters in the Global North, should limit themselves to funding, support and coordination services; they could even preferably move their headquarters to countries in the Global South. This would mean giving up the dichotomous narrative of "rescuers" and "victims" for the sake of strengthening the agency of affected people, local organizations and initiatives in organizing to provide aid to themselves and others. International and local organizations would understand themselves as working towards a common goal, which would be to reduce the inequality between donor and recipient countries during the COVID-19 pandemic-and beyond. Localization could thus lead to more solidarity, if it would strengthen the agency of "locals" and shifting responsibilities and resources to organizations in the Global South, whereby international organizations would support this shift and work towards identifying common goals. To be sure, this is still an ideal or vision. Under the current pandemic conditions, a few steps seem to have been made in this direction, as successful pandemic response requires functioning institutions at the local level.

The mobility of Western humanitarian and development aid workers was reduced through lockdown-measures and general mobility restrictions, as they were possible carriers of the disease. Those aid workers that were present in zones of conflict, such as the Democratic Republic of Congo (DRC), also failed to earn the trust of the local population. Doctors without Borders self-critically explains, for example, that they had lost trust when focusing on Ebola only, ignoring other health issues, when they tried to counter a recent Ebola outbreak during the COVID-19 pandemic. On the contrary, the DRC's government had learnt from dealing with earlier Ebola outbreaks and measles and focused on strengthening the health system in general (Adepoju, 2020, p. 1). In the DRC trust was rather gained through community engagement in the Ebola epidemic, which is an important lesson to be learnt also for dealing with COVID-19: "peacekeepers, healthcare workers, aid organisations and local bodies need to work together to ensure that the effects of COVID-19 in conflict zones are mitigated" (Banerjee, 2020, p. 448). 
The COVID-19 pandemic thus sheds light on developments towards localization that helped to successfully cope with the situation within certain countries. For sure, the impact of these local approaches to control the pandemic should not be overestimated. Global emergencies, such as the pandemic, but also large-scale migration, demand long-term international solutions, next to local actions. Otherwise there is a real risk that voluntary civil local initiatives simply substitute and by way of this cover up the lack of political will and actions (Haaland and Wallevik, 2020, p. 1880). The COVID-19 response in conflict zones highlights nevertheless that localization bears a chance for solidarity in humanitarian aid, at least when the strengthening of local community actors translates into political action to achieve common goals among equals. By reducing inequalities in the

\section{REFERENCES}

Adepoju, P. (2020). Lessons from Ebola as DRC Grapples with Conflict, Measles, and Covid-19. BMJ 370, m2879. doi:10.1136/bmj.m2879

Ärzte ohne Grenzen (2020). EU-Staaten dürfen Covid-19 nicht zur Behinderung der Seenotrettung instrumentalisieren. Available online at: https://www. theglobalfund.org/media/10776/covid-19_2020-disruption-impact_report_en. pdf (Accessed 9 29, 2021).

Auswärtiges Amt (2018). Humanitarian Aid is an Expression of Solidarity. Available online at: https://www.auswaertiges-amt.de/en/aussenpolitik/ themen/humanitarianassistance/maas-maurer-icrc/2136654 (Accessed September 13, 2020).

Auswärtiges Amt (2020a). Effects of the COVID-19 Crisis on the Global Humanitarian Situation and its Misuse by Autocratic Governments to Restrict Human Rights. Available online at: https://www.auswaertigesamt.de/en/newsroom/news/maas-bt-corona/2341308 (Accessed May 15, 2020).

Auswärtiges Amt (2020b). Video Address by Federal Foreign Minster Heiko Maas on the Occasion of the Presentation of the United Nations Global Humanitarian Overview 2021 from Berlin. Available online at: https://www.auswaertiges-amt. de/en/newsroom/news/maas-global-humanitarian-overwiew/2422042 (Accessed December 1, 2020).

Bandsom, K. (2020). Humanitäre Hilfe während der Corona-Krise. Available online at: https://www.welthungerhilfe.de/aktuelles/blog/2020/humanitaerehilfe-waehrend-der-corona-krise/ (Accessed 9 29, 2021).

Banerjee, S. (2020). Mitigating the Impact of COVID-19 in Conflict Zones. Interdiscip. Descr. Complex Syst. 18 (4), 446-448. doi:10.7906/indecs.18.4.4

Barnett, M. (2005). Humanitarianism Transformed. Perspect. Polit. 3 (4), 723-740. doi:10.1017/s1537592705050401

Barnett, M. N. (2020). Humanitarianism and Human Rights: A World of Differences?. Cambridge: Cambridge University Press.

Bogdandy, A. V., and Villareal, P. (2020). "The Role of International Law in Vaccinating against COVID-19: Appraising the COVAX Initiative," in MPIL Research Paper No. 2020-46. Max Planck Institute for Comparative Public Law and International Law (Heidelberg: SSRN), 89-116. doi: $10.2139 /$ ssrn. 3733454

Dany, C. (2019). Exploring the Political Agency of Humanitarian NGOs: Médecins Sans Frontières during the European Refugee Crisis. Glob. Soc. 33 (2), 184-200. doi:10.1080/13600826.2019.1577804

Derpmann, S. (2020). "Solidarität," in Handbuch Gemeinwohl. Editor C. Hiebaum (Wiesbaden: Springer), 1-13. doi:10.1007/978-3-658-21086-1_9-1

ECHO (2008). What is Solidarity? Humanitarian Aid Brochure. Available online at: https://ec.europa.eu/echo/files/media/publications/solidarity_en.pdf.

Etzold, B. (2020). In the Shadow of the Pandemic: Who Has a Right to Mobility - and Who Doesn't? Annual Report. Bonn: BICC. Available online at: https://www.bicc.de/uploads/tx_bicctools/BICC_AR_2020_Essay.pdf (Accessed 9 29, 2021). humanitarian aid system, the localization agenda may contribute to include solidarity in humanitarian practice.

\section{DATA AVAILABILITY STATEMENT}

The original contributions presented in the study are included in the article/supplementary material, further inquiries can be directed to the corresponding author.

\section{AUTHOR CONTRIBUTIONS}

The author confirms being the sole contributor of this work and has approved it for publication.

European Commission (2020). Commission Recommendation of 23.9.2020 on Legal Pathways to protection in the EU: Promoting Resettlement, Humanitarian Admission and Other Complementary Pathways. C(2020) 6467 Final. Available online at: https://ec.europa.eu/info/sites/info/files/ commission_recommendation_on_legal_pathways_to_protection_in_the_eu_ promoting_resettlement_humanitarian_admission_and_other_complementary_ pathways.pdf (Accessed 9 29, 2021).

Flynn, J. (2020). "Suffering and Status," in Humanitarianism and Human Rights: A World of Differences?. Editor M. N. Barnett (Cambridge: Cambridge University Press), 49-70. doi:10.1017/9781108872485.003

Haaland, H., and Wallevik, H. (2020). Beyond Crisis Management? the Role of Citizen Initiatives for Global Solidarity in Humanitarian Aid: The Case of Lesvos. Third World Q. 40 (10), 1869-1883. doi:10.1080/ 01436597.2019.1656060

Lucke, A. V. (2021). 1 Jahr Corona: Ende Oder Wende? Blätter für deutsche und internationale Politik 66 (1), 5-8.

Nott, D. (2020). The COVID-19 Response for Vulnerable People in Places Affected by Conflict and Humanitarian Crises. The Lancet 395, 1532-1533. doi:10.1016/ s0140-6736(20)31036-9

OCHA (2020). Geneva/ Global Humanitarian Overview: UNTV CH, 2020. Available online at: https:/www.unmultimedia.org/tv/unifeed/asset/2586/ 2586261/ (Accessed 9 29, 2021).

Prizzon, A. (2020). How Coronavirus Is Accelerating a New Approach to International Cooperation. Available online at: https://www.odi.org/blogs/ 16794-how-coronavirus-accelerating-new-approach-international-cooperation (Accessed 9 29, 2021).

Razavi, S., Behrendt, C., Bierbaum, M., Orton, I., and Tessier, L. (2020). Reinvigorating the Social Contract and Strengthening Social Cohesion: Social protection Responses to COVID-19. Int. Soc. Security Rev. 73 (3), 55-80. doi:10.1111/issr.12245

Roepstorff, K. (2020). A Call for Critical Reflection on the Localisation Agenda in Humanitarian Action. Third World Q. 41 (2), 284-301. doi:10.1080/ 01436597.2019.1644160

Rozakou, K. (2017). Solidarity \#Humanitarianism. The Blurred Boundaries of Humanitarianism in Greece. Etnofoor, Solidarity 29 (2), 99-104.

Schenkenberg (2016). The Challenges of Localised Humanitarian Aid in Armed Conflict. Emergency Gap Series 03. Medecins Sans Frontieres. Available online at: https://arhp.msf.es/sites/default/files/MSF_EGS03_The\%20challenges\%20of $\% 20$ localised\%20humanitarian\%20aid\%20in\%20armed\%20conflict_november\% 202016_0_0.pdf (Accessed 9 29, 2021).

Slim, H. (2015). Humanitarian Ethics: A Guide to the Morality of Aid in War and Disaster. New York, NY: Oxford University Press.

The Global Fund (2021). The Impact of COVID-19 on HIV, TB and Malaria Services and Systems for Health: A Snapshot from 502 Health Facilities across Africa and Asia. Available online at https://www.theglobalfund.org/media/ 10776/covid-19_2020-disruption-impact_report_en.pdf (Accessed 9 29, 2021).

Ticktin, M. (2014). Transnational Humanitarianism. Annu. Rev. Anthropol. 43 (1), 273-289. doi:10.1146/annurev-anthro-102313-030403 
UN News (2020). COVID-19 Shows 'urgent Need' for Solidarity, UN Chief Tells Nobel Forum. Available online at https://news.un.org/en/story/2020/12/ 1079802 (Accessed 9 29, 2021).

van Dyk, S. (2020). "Von der Nothilfe zur politischen Ökonomie des Helfens. Flüchtlingshilfe in der Freiwilligengesellschaft," in Fluchtmigration und Gesellschaft. Von Nutzenkalkülen, Solidarität und Exklusion. Editors K. Binner and K. Scherschel (Weinheim: Beltz Juventa), 32-49.

Wagner, G. (2019). Stichwort: Helfen zwischen Solidarität und Wohltätigkeit. WestEnd - Neue Z. für Sozialforschung 1, 87-90.

Conflict of Interest: The author declares that the research was conducted in the absence of any commercial or financial relationships that could be construed as a potential conflict of interest.
Publisher's Note: All claims expressed in this article are solely those of the authors and do not necessarily represent those of their affiliated organizations, or those of the publisher, the editors and the reviewers. Any product that may be evaluated in this article, or claim that may be made by its manufacturer, is not guaranteed or endorsed by the publisher.

Copyright $\odot 2021$ Dany. This is an open-access article distributed under the terms of the Creative Commons Attribution License (CC BY). The use, distribution or reproduction in other forums is permitted, provided the original author(s) and the copyright owner(s) are credited and that the original publication in this journal is cited, in accordance with accepted academic practice. No use, distribution or reproduction is permitted which does not comply with these terms. 